Asian J. Med. Biol. Res. 2015, 1 (1), 59-64

\author{
Asian Journal of \\ Medical and Biological Research \\ ISSN 2411-4472 \\ www.ebupress.com/journal/ajmbr
}

\title{
Article \\ Epidemiology of infectious bursal disease in broiler birds of three districts in Bangladesh
}

\author{
Shovon Chakma* \\ Institute of Epidemiology, Disease Control \& Research, Dhaka, Bangladesh \\ *Corresponding author: Shovon Chakma, Institute of Epidemiology, Disease Control \& Research, Dhaka, \\ Bangladesh. E-mail: shovonchakma@gmail.com
}

Received: 18 May 2015/Accepted: 17 June 2015/ Published: 30 June 2015

\begin{abstract}
A cross-sectional study was conducted in 450 broiler farms of three districts of Bangladesh from June 2012 to July 2013. The estimated prevalence and mortality of infectious bursal disease (IBD) in three districts were $10.2 \%(\mathrm{CI}, 9.2-11.2)$ and $7.8 \%$ (CI, 6.4-9.2) respectively. On clinical sign such as anorexia, ruffled feathers and diarrhoea and necropsy gross changes at bursa of fabricius, the highest prevalence was recorded in Comilla district (10.4\%) followed by Feni district (10.3\%) and Chittagong district (10.0\%), while the highest mortality was recorded in the same Comilla district (8.3\%) followed by Chittagong district (8.1\%) and Feni district $(7.0 \%)$. IBD was recorded year-round and had significant association $(\mathrm{P}<0.05)$ with season. Significantly higher prevalence $(13.1 \%)$ and mortality $(9.8 \%)$ was documented in winter season. Broiler chicken age between 21-30 days was significantly reported with high prevalence rate and high mortality rate. The study result indicated the difference of IBD occurrence in Bangladesh, thereby would support to improve the current control plans.
\end{abstract}

Keywords: infectious bursal disease; broiler; prevalence; mortality rate

\section{Introduction}

Infectious bursal disease (IBD) is an acute, highly contagious, immunosuppressive and economically important poultry disease caused by Birnaviridae RNA virus (Cosgrove, 1962; Lukert and Saif, 2003; Islam, 2005; Okwor et al., 2011). The disease damage the humoral immunity producing lymphoid organ Bursa of Fabricius and result in immuno-suppression and increase susceptibility of poultry to opportunistic secondary infection such as Marek's disease and Newcastle disease (Faragher et al., 1974; Homer et al., 1992; Khan et al., 2011; Mahgoub, 2012). Broiler bird aged between 21-30 days are most susceptible to IBD infection (Mor et al., 2010). Subclinical IBD infection in less than 2 weeks aged chickens caused immunosuppression (Ley et al., 1979). Infectious bursal disease was reasonably controlled by successful vaccination (Al-Natour et al., 2004), however, in some cases vaccinations have been unsuccessful in protecting birds (Islam et al., 2003).

Infectious bursal disease in poultry farms of different region of Bangladesh has been documented (Ahmed $e t$ al., 2009; Bhattacharjee et al., 1996; Biswas et al., 2005; Giasuddin et al., 2002; Hasan et al., 2012; Hossain et al., 2004; Islam and Samad, 2003; Islam et al., 2003; Islam et al., 1998; Rahman and Samad, 2012; Salam et al., 2011; Talha et al., 2001). Several factors like vaccination status, biosecurity measure, management practice and climatic condition may play an important role in the prevalence of IBD. Department of Livestock Service (DLS) of Government of Bangladesh produce infectious bursal disease vaccine and distributes at a subsidize rate to the poultry farmer for successful control of this disease. Despite this measure, infectious bursal disease is a common disease in poultry farm of Bangladesh. Therefore, knowledge on infectious bursal disease 
epidemiology is necessary for to implement a successful prevention-control program at farm level. The study was take on to understand the epidemiology of infectious bursal disease in Bangladesh.

\section{Materials and Methods}

A survey was conducted on 450farms in 6 upazilas of three districts: Feni sadar and Fulgazi of Feni district, Comilla dakshin and Chouddagram of Comilla district, Sitakunda and Mirsharai of Chittagong district during June 2012-July 2013 study period. The three districts were purposively selected as poultry development project has been implemented by several NGO's. The upazilas were randomly selected by lottery from a list of upazilas. Broiler farms were selected from a list of poultry farm that were known to keep in Upazila Livestock office and 150 farms, having at least 30 broiler farm in the upazila, from in each upazila were randomly selected. The required number of farm from each district was 150 based on the formula $n=Z^{2} * P Q / L 2$ (Biswas $e t$ al., 2005) [here, $n=$ sample size, $P=$ expected prevalence, $Q=1-P$ and $L=$ precision]. The prevalence of IBD was documented, $11.06 \%$ in Gazipur (Ahmed et al., 2009). Therefore, prevalence $P=0.11$, a precision $L=0.05$ and confidence level $95 \% Z=1.96$ was considered in the calculation.

Six field technicians, one for each upazila, and one veterinarian were recruited to monitor the field technicians activity in study sites. Field technicians were trained before sending them for farm investigation. A record keeping book designed by principle investigator was provided to each broiler farm to record relevant information relating to the study. Staff of each poultry farm was trained by veterinarian on how to recognize clinical signs of disease and how to maintain the record in the notebook.

Field technician was scheduled to visit broiler farms at least twice a week and collected information (breed, sex, age of birds, medication history and vaccination history) as well as broiler chicken carcass if required. However, technician was responsible to visit poultry farm other than the scheduled visit if they obtain request, over phone, from poultry farm to collect dead broiler chicken carcass. Farmers were paid Bangladeshi Taka 40 for each dead chicken. Dead chicken was marked with an identification number, placed in an ice-packed cool box and bring it to Upazila Livestock Office or Field Disease Investigation Laboratory (FDIL) for systemic necropsy. The observed post-mortem changes were recorded during necropsy.

Due to limitations of resources, diagnosis was made on the basis of notebook recorded clinical signs and observer gross pathological lesions during necropsy in the dead chicken. The following sets of clinical signs and post-mortem lesions were considered as indicative of the IBD diseases (Chowdhury et al., 1996; Zeleke et al., 2005).

Clinical signs- Anorexia, depression, ruffled feather, diarrhoea and death. Death common at 21-30 days of age; mortality reached a peak within 2-3 days of onset.

Post-mortem lesions- Emaciated and highly dehydrated carcass, congestion in blood vessel (sub-cutaneous), leg and breast muscle, swollen and edematous bursa of fabricious with yellowish or creamy discoloration, sometimes serosal and mucosal haemorrhage and congestion of bursa and atrophied bursa.

Data was recorded in the Microsoft Excel 2010 and statistical analysis was performed by STATA 13. Mortality and prevalence rate were calculated by the above mentioned formula (Rashid et al., 2010).

Prevalence rate $=\frac{\text { Number of affected bird }}{\text { Total number of birds }} X 100$

Mortality rate $=\frac{\text { Number of dead birds during the study period }}{\text { Total number of birdss }} X 100$

The significant association ( $\mathrm{p}$-value $<0.05$ ) between variable was recorded using Chi-square test.

\section{Results}

This study was conducted in a total of 450 broiler farms of three districts of Bangladesh over 14 months (June 2012-July 2013). The total number of broiler chicken was 52050. The study finding as per study areas, seasonal variation, age groups and vaccination status are documented in Table 1 . The estimated occurrence and mortality rate of IBD in three districts were 10.2\% (CI, 9.2-11.2) and 7.8\% (CI, 6.4-9.2) respectively. The highest prevalence was recorded in Comilla district (10.4\%) followed by Feni district (10.3\%) and Chittagong district (10.0\%), while the highest mortality was recorded in the same Comilla district (8.3\%) followed by Chittagong district $(8.1 \%)$ and Feni district $(7.0 \%)$. IBD was recorder year-round in the study sites. IBD had significant $(\mathrm{p}<0.5)$ association with season and recorded with significantly $(\mathrm{P}<0.05)$ higher in prevalence and mortality 
rate during winter $(13.1 \%$ and $9.8 \%)$ and rainy (10.6\% and $8.5 \%)$ season compared to summer $(9.7 \%$ and $7.1 \%)$ and autumn (8.2\% and 6.3\%). Broiler chicken age between 21-30 days reported significantly $(\mathrm{P}<0.5)$ higher IBD prevalence $(13.8 \%)$ and mortality rate $(11.2 \%)$. The second highest prevalence $(10.9 \%)$ and mortality rate $(8.6 \%)$ was recorded during age 11-20 days. The disease was reported very low during age 1-10 days. Of the 450 broiler farms, 204 farms were reported with a history of single dose of IBD vaccine followed by 150 unvaccinated and 96 booster dose broiler farm. IBD was recorded with significantly $(\mathrm{p}<0.5)$ higher in prevalence and mortality rate in unvaccinated and single dose vaccination flock.

Table 1. Prevalence and Mortality rate of IBD in broiler chicken of Bangladesh (June 2012- July 2013).

\begin{tabular}{|c|c|c|c|c|c|c|c|c|c|}
\hline \multirow[t]{2}{*}{ Variable } & \multirow[t]{2}{*}{ Group } & \multirow{2}{*}{$\begin{array}{l}\text { Total } \\
\text { flocks }\end{array}$} & \multirow[t]{2}{*}{ PAR* } & \multicolumn{2}{|c|}{ Mortality } & \multirow[t]{2}{*}{ P-value } & \multicolumn{2}{|c|}{ Prevalence } & \multirow[t]{2}{*}{ P-value } \\
\hline & & & & No. & $\%$ & & No. & $\%$ & \\
\hline \multirow{6}{*}{$\begin{array}{l}\text { Study } \\
\text { areas }\end{array}$} & Comilla dakshin & 88 & 85700 & 7500 & 8.8 & \multirow{5}{*}{$<0.5$} & 9430 & 11.0 & \multirow{6}{*}{$<0.5$} \\
\hline & Chouddagram & 62 & 52670 & 3960 & 7.5 & & 4959 & 9.4 & \\
\hline & Feni Sadar & 68 & 75600 & 5458 & 7.2 & & 7230 & 9.6 & \\
\hline & Fulgazi & 82 & 78545 & 5358 & 6.8 & & 8590 & 10.9 & \\
\hline & Mirsharai & 70 & 52850 & 4180 & 7.9 & & 5057 & 9.6 & \\
\hline & Sitakunda & 80 & 72090 & 5927 & 8.2 & & 7480 & 10.3 & \\
\hline \multirow[t]{4}{*}{ Season } & $\begin{array}{l}\text { Winter } \\
\text { (Dec-Feb) }\end{array}$ & 166 & 110500 & 10860 & 9.8 & \multirow{4}{*}{$<0.5$} & 14500 & 13.1 & \multirow{4}{*}{$<0.5$} \\
\hline & $\begin{array}{l}\begin{array}{l}\text { Summer } \\
\text { (Mar-May) }\end{array} \\
\end{array}$ & 88 & 100655 & 7172 & 7.1 & & 8762 & 9.7 & \\
\hline & Rainy (Jun-Aug) & 71 & 60700 & 5180 & 8.5 & & 7500 & 10.6 & \\
\hline & $\begin{array}{l}\text { Autumn } \\
\text { (Sep-Nov) } \\
\end{array}$ & 125 & 145600 & 9171 & 6.3 & & 11984 & 8.2 & \\
\hline \multirow{4}{*}{$\begin{array}{l}\text { Age } \\
\text { (days) }\end{array}$} & $1-10$ & 55 & 45750 & 345 & 0.8 & & 845 & 1.8 & \\
\hline & $11-20$ & 140 & 125115 & 10780 & 8.6 & & 13595 & 10.9 & \\
\hline & $21-30$ & 189 & 187900 & 21090 & 11.2 & $<0.5$ & 25856 & 13.8 & $<0.5$ \\
\hline & $>30$ & 66 & 58690 & 1680 & 2.9 & & 2450 & 4.2 & \\
\hline \multirow[t]{3}{*}{$\begin{array}{l}\text { Vaccinati } \\
\text { on status }\end{array}$} & \begin{tabular}{|ll} 
Single & dose \\
Vaccination & \\
\end{tabular} & 204 & 210900 & 17965 & 8.5 & $<0.5$ & 20045 & 9.5 & $<0.5$ \\
\hline & \begin{tabular}{|ll} 
Booster & dose \\
vaccination & \\
\end{tabular} & 96 & 85985 & 4184 & 4.9 & & 5826 & 6.8 & \\
\hline & unvaccinated & 150 & 120570 & 10234 & 8.5 & $<0.5$ & 16875 & 14.0 & $<0.5$ \\
\hline
\end{tabular}

*PAR= Population at risk

\section{Discussion}

The study result provides information on the age and seasonal distribution of IBD in the three district of Bangladesh. The estimated prevalence of IBD (10.2\%) in Bangladesh was closely consistent with the previous study result (Ahmed et al., 2009; Bhattacharjee et al., 1996; Giasuddin et al., 2002; Islam and Samad, 2003; Rahman and Samad, 2012; Rashid et al., 2010). However, higher prevalence of IBD has been reported by other researcher (Biswas et al., 2005; Hasan et al., 2012; Hossain et al., 2004; Islam et al., 2003; Islam et al., 1998; Salam et al., 2011; Talha et al., 2001). IBD mortality rate (7.8\%) of this study has been recorded higher in compare to other studies of Bangladesh (Rahman et al., 2010; Rashid et al., 2010; Shil et al., 2003) may indicative to geographical variation of different disease control practice and biosecurity measurement among broiler farms. The higher prevalence and mortality rate reported in this study therefore support the findings of researchers (Boon et al., 2007; Rashid et al., 2013) that possession of old litter, lack of restriction in animals, birds, contaminated vehicles, personnel with contaminated shoes and clothing movement within the farm area might contribute to the IBD occurrence in broiler farms of Bangladesh.

Season had substantial effect on IBD occurrence $(\mathrm{P}<0.05)$ in Bangladesh. The occurrence of IBD was reported higher (9.8\%) in this study and was agreed with earlier findings (Biswas et al., 2005; Farooq et al., 2003; Rashid et al., 2010). However, higher IBD was reported in season other than winter was reported in Bangladesh (Islam et al., 2009; Islam et al., 2003; Rahman and Samad, 2012). In the study sites it was observed that broiler 
farms used polythene sheets during winter season to protect their flock from extreme cold in which supports the finding of Mor et al., 2010 that close interaction of birds in the air tight poultry sheds attributable to airborne production of IBDV in the flock. Higher prevalence and mortality has been also reported during rainy season. It assumes that heavy rainfall attributed high humidity in the poultry shed result in high IBD occurrence in the broiler farm. This finding was also consistent with other researcher findings (Mor et al., 2010).

The occurrence of IBD was recorded with significantly higher $(\mathrm{P}<0.05)$ in broiler age between 21-30 days of age which is supportive to the study finding of other researchers (Anku, 2003; Bekhit, 1997; Mor et al., 2010; Saif-Edin et al., 2000). Higher incidence of IBD in broiler has been documented during $4^{\text {th }}$ week of age followed by $5^{\text {th }}, 3^{\text {rd }}$ and $6^{\text {th }}$ weeks of age (Ahmad et al., 1993; Jaisankar et al., 2003; Sami and Baruah, 1997; Zeleke et al., 2005). Lower IBD in broiler age between 1-10 days indicative to protective maternal antibody level in broiler chicks, while occurrence of IBD in broiler $>30$ days of age indicative to improper IBD vaccination in the broiler farm.

Vaccination status of broiler had a noteworthy association with IBD occurrence and mortality rate. In this study, IBD was recorded both in unvaccinated and vaccinated flock (single dose and booster dose). This result support the finding of earlier researcher (Anku, 2003; Islam and Samad, 2003; Jindal et al., 2004; Muhammad et al., 1996; Wang et al., 2009) who documented IBD in vaccinated flock. The study finding also in conformity with the suggestion of Sivaseelan and Balachandran (1999) that lack of maternal antibodies and failure of vaccine may attributable to the occurrence of IBD in an unvaccinated flock (Sivaseelan and Balachandran, 1999). Overall, the study finding highlights again the importance of proper vaccination practices, maintenance of cool chain, chlorination of water and reduction of vaccine exposure time to environment for successful prevention and control of IBD occurrence in the poultry flocks.

\section{Conclusions}

It can be concluded from this study that infectious bursal disease is present throughout the year in Bangladesh. The frequency of IBD infection increased during winter season and is associated with bird age. Therefore, it is noteworthy to encourage farmer to adapt biosecurity tool and vaccinate the broiler regularly and properly to reduce the further loss.

\section{Conflict of interest}

None to declare.

\section{References}

Ahmad K, N Arshad and SM Rizvi, 1993. Incidence of infectious bursal disease (gumboro) in broilers. Proceedings of Pakistan Congress of Zoology, pp. 501-504.

Ahmed M, A Sarker and M Rahman, 2009. Prevalence of infectious diseases of broiler chickens in Gazipur district. Bangl. J. Vet. Med., 7: 326-331.

Al-Natour M, L Ward, Y Saif, B Stewart-Brown and L Keck, 2004. Effect of different levels of maternally derived antibodies on protection against infectious bursal disease virus. Avian Dis., 48: 177-182.

Anku GG, 2003. Gumboro hampers efforts to improve nutrition of Ghana's growing population-Current trends and methods of control. Poult. Int., 42: 32-35.

Bekhit A, 1997. Highly virulent form of infectious bursal disease in Egypt: Some epidemiological observations. Indian J. Anim. Sci., 67.

Bhattacharjee PS, RI Kundu, RK Biswas, JU Mazumder, E Hossain and AH Miah, 1996. A retrospective analysis of chicken diseases diagnosed t the Central Disease Investigation Laboratory, Dhaka. Bangladesh Veterinary Journal, 30: 105-113.

Biswas PK, D Biswas, S Ahmed, A Rahman and NC Debnath, 2005. A longitudinal study of the incidence of major endemic and epidemic diseases affecting semi-scavenging chickens reared under the Participatory Livestock Development Project areas in Bangladesh. Avian Pathol., 34: 303-312.

Boon AC, MR Sandbulte, P Seiler, RJ Webby, T Songserm, Y Guan, and RG Webster, 2007. Role of terrestrial wild birds in ecology of influenza A virus (H5N1). Emerg. Infect. Dis.,13: 1720-1724.

Chowdhury EH, MR Islam, PM Das, ML Dewan and MSR Khan, 1996. Acute infectious bufisal disease in chickens: pathological observation and virus isolation. Asian Australas. J. Anim. Sci., 9: 465-469.

Cosgrove A, 1962. An apparently new disease of chickens: avian nephrosis. Avian Dis., 6: 385-389. 
Faragher J, W Allan and P Wyeth, 1974. Immunosuppressive effect of infectious bursal agent on vaccination against Newcastle disease. Vet. Rec., 95: 385-388.

Farooq M, FR Durrani, N Imran and Z Durrani, 2003. Prevalence and economic losses due to infectious bursal disease in broilers in Mirpur and Koti districts of Kashmir. Int. J. Poult. Sci., 2: 267-270.

Giasuddin M, B Sil, J Alam, I Koike, M Islam and M Rahman, 2002. Prevalence of poultry diseases in Bangladesh. J. Biol. Sci., 2: 212-213.

Hasan AR, MH Ali, MP Siddique, MM Rahman and MA Islam, 2012. Clinical and laboratory diagnoses of newcastle and infectious bursal diseases of chickens. Bangl. J. Vet. Med., 8: 131-140.

Homer BL, GD Butcher, RD Miles and AF Rossi, 1992. Subclinical infectious bursal disease in an integrated broiler production operation. J. Vet. Diag. Invest., 4: 406-411.

Hossain M, M Ahmed, H Kabir, M Sarker, M Jail andG Adhikary, 2004. Poultry diseases at Rajshahi in Bangladesh. J. Anim. Vet. Adv., 3: 656-658.

Islam A, A Trisha, M Das and M Amin, 2009. Retrospective study of some poultry diseases at Gaibandha district in Bangladesh. Bangl. J. Vet. Med., 7: 239-247.

Islam $M$ and $M$ Samad, 2003. Outbreaks of infectious bursal disease in vaccinated and unvaccinated commercial cockerel farms in Bangladesh. Bangl. J. Vet. Med., 1: 21-24.

Islam M, 2005. A manual for the production of BAU 404 Gumboro vaccine. Report submitted to the Department of Livestock Services, Dhaka, Bangladesh.

Islam MR, BC Das, K Hossain, NS Lucky and MG Mostafa, 2003. A study on the occurrence of poultry diseases in Sylhet region of Bangladesh. Int. J. Poult. Sci., 2: 354-356.

Islam MR, MAHNA Khan, PM Das and ASM Bari, 1998. Poultry diseases diagnosed at necropsy in 1997 and 1998 in the Department of Pathology of Bangladesh Agricultural University, Mymensingh. Proceedings of 5th BSVER Annual Scientific Conference, Mymensingh, Bangladesh.

Jaisankar S, A Manicavasakadinakaran and K Karunakaran, 2003. Retrospective studies on the pattern of viral diseases in poultry in Namakkal. Indian J. Poult. Sci.,38: 142-144.

Jindal N, N Mahajan, D Mittal, S Gupta and R Khokhar, 2004. Some epidemiological studies on infectious bursal disease in broiler chickens in parts of Haryana, India. Int. J. Poult. Sci., 3: 478-482.

Khan MY, M Arshad, MS Mahmood and I Hussain, 2011. Epidemiology of Newcastle disease in rural poultry in Faisalabad, Pakistan. Int. J. Agri. Biol.,13: 491-497.

Ley D, N Storm, A Bickford and R Yamamoto, 1979. An infectious bursal disease virus outbreak in 14-and 15week-old chickens. Avian Dis., 23: 235-240.

Lukert PD and YM Saif, 2003. Infectious Bursal Disease, InDiseases of Poultry, Eds., Saif, YM, AM Fadly, JR Glisson, LR McDougald, LK Nolan, and DE Swayne.Iowa State Press, Ames., Iowa, pp. 721-738.

Mahgoub HA, 2012. An overview of infectious bursal disease. Arch.Virol.,157: 2047-2057.

Mor SK, G Narang, N Jindal, N Mahajan, P Sharma and N Rakha, 2010. Epidemiological studies on infectious bursal disease in Broiler Chickens in Haryana, India. Int. J. Poult. Sci., 9: 395-400.

Muhammad K, A Muneer, MS Anwer and MT Yaqub, 1996. Failure of vaccine to control infectious bursal disease in commercial poultry. Pak. Vet. J., 16: 119-121.

Okwor EC, DC Eze and K Okonkwo, 2011. Serum Antibody Levels against Infectious Bursal Disease Virus in Nigerian Village Chickens. Pak. Vet. J., 32: 286-287.

Rahman MA and MA Samad, 2012. Important viral diseases associated with mortality of layer chickens in commercial poultry farms in Bangladesh. Bangl. J. Vet. Med., 3: 1-5.

Rahman MS, MS Islam, MT Rahman, NH Parvez and MM Rahman, 2010. Analysis of prevalence of infectious Bursal disease in broiler flocks in Dinajpur. Int. J. Sust. Crop Prod., 5: 15-18.

Rashid MH, C Xue, MT Islam, MR Islam and Y Cao, 2013. Risk factors associated with infectious bursal disease in commercial chickens in Bangladesh. Prev. Vet. Med., 111: 181-185.

Rashid MH, C Xue, MT Islam, MR Islam, Z She and Y Cao, 2013. Comparative epidemiological study of infectious bursal disease of commercial broiler birds in Bangladesh and China. Pak. Vet. J., 33:160-161.

Saif-Edin M, M Aly, A El-Aziz and F Mohamed, 2000. Epidemiological studies on Gumboro disease in upper Egypt. Assiut Veterinary Medical Journal, 42: 223-241.

Salam MA, SMH Rashid, MF Hoque, MM Islam and MF Hossain, 2011. Study of pathological conditions encountered in small scale commercial broiler farms at sadar upazilla of Dinajpur district of Bangladesh. Bangl. Res. Pub. J., 5: 111-116. 
Sami W and GK Baruah, 1997. Incidence of infectious bursal disease in broilers in Assam. Indian J. Vet. Pathol., 21: 67-68.

Shil GC, MA Ehsan, MS Rahman, AKMM Anower and MR Islam, 2003. Diseases associated with mortality and pathological changes in cockerel birds. Bangl. J. Vet. Med., 1: 33-38.

Sivaseelan S and C Balachandran, 1999. A study on the pathology of infectious bursal disease under natural and experimental condition. Indian Vet. J., 76: 599-602.

Talha A, M Hossain, EH Chowdhury, ASM Bari, MR Islam and PM Das, 2001. Poultry diseases occurring in Mymensingh district of Bangladesh. Bangladesh Veterinarian,18: 20-23.

Wang G, F Qian and L Ping, 2009. The epidemic characteristics and comprehensive prevention control of infectious bursal disease in our country. China Dis. Control, 143: 25-27.

Zeleke A, E Gelaye, T Sori, G Ayelet, A Sirak and B Zekarias, 2005. Investigation on infectious bursal disease outbreak in Debre Zeit, Ethiopia. Int. J. Poult. Sci., 4: 504-506. 